\title{
Studies on the Relationship between Plasma Free Fatty Acids and Growth Hormone Secretion in Man
}

\author{
Hans-Jürgen Quabbe, Hans-Jürgen Bratzke, Ulrike Siegers, \\ and KADIP ELBAN \\ From the Medizinische Klinik und Poliklinik, Klinikum Steglitz, Freie \\ Universität, D-1 Berlin 45, Germany
}

A B S T RACT The influence of plasma free fatty acid (FFA) concentration on the secretion of human growth hormone (HGH) was investigated. (a) FFA depression was produced by means of a nicotinic acid (NA) infusion for either 1 or $5 \mathrm{hr}$ in the presence of glucoseinduced hyperglycemia. Controls received only saline. (b) FFA depression was also produced by a 90 min NA infusion and then rapid FFA elevation by a lipid-plusheparin (lipid) infusion. This procedure was compared with a similar NA infusion not followed by lipid. (c) FFA elevation was produced either by a lipid or by a norepinephrine (NE) infusion and then HGH secretion was stimulated by insulin-induced hypoglycemia. Each subject in this group received both the lipid and the $\mathrm{NE}$ infusion on seperate days as well as two control tests (insulin alone and $\mathrm{NE}$ alone).

Depression of FFA resulted in an increase of $\mathrm{HGH}$ with a lag period of approximately $2 \mathrm{hr}$. Maximal HGH rise after $1 \mathrm{hr}$ NA infusion was $7.7 \pm 1.9 \mathrm{ng} / \mathrm{ml}$ and with $5 \mathrm{hr}$ NA infusion $14.3 \pm 3.6 \mathrm{ng} / \mathrm{ml}$ (both significantly higher than during saline infusion, $P<0.025$ and $<0.005$ respectively) and occurred despite continuous hyperglycemia. Lipid infusion just before the expected $\mathrm{HGH}$ increase prevented the HGH response to FFA de-

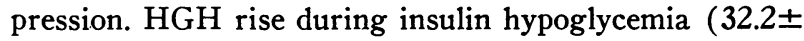
$6.5 \mathrm{ng} / \mathrm{ml}$ ) was significantly inhibited by prior FFA elevation whether achieved by lipid infusion (maximum $\mathrm{HGH}$ rise $11.4 \pm 1.6 \mathrm{ng} / \mathrm{ml}$ ) or by $\mathrm{NE}$ infusion (maximum HGH rise $19.0 \pm 6.2 \mathrm{ng} / \mathrm{ml}$ ).

The results are suggestive of a negative feedback loop

The results of this work were presented at the 2nd International Symposium on Growth Hormone, Milan, Italy, 5-7 May 1971.

This work was supported by Deutsche Forschungsgemeinschaft.

Received for publication 7 February 1972 and in revised form 27 March 1972. between plasma FFA and HGH secretion, of importance for subacute rather than acute changes in the plasma FFA concentration. FFA lack itself seems to be the signal for HGH release despite the lag period between FFA decrease and $\mathrm{HGH}$ increase. Glucose and FFA can at least not fully replace each other in their respective influence on $\mathrm{HGH}$ release.

\section{INTRODUCTION}

While the lipolytic activity of (human growth hormone) ${ }^{1}$ HGH is well recognized $(1,2)$, evidence for a possible influence of plasma free fatty acid (FFA) on HGH secretion has only recently been sought. Irie, Sakuma, Tsushima, Shizume, and Nakao (3) and later Tsushima, Matsuzaki, and Irie (4) showed that FFA depression is followed by an increase of plasma HGH. Blackard, Boylen, Hinson, and Nelson (5) and Blackard, Hull, and Lopez-S (6) reported that FFA elevation inhibits HGH release in the monkey and in man. In two other reports, however, no GH increase was seen after FFA depression in monkeys (7) and no inhibition of HGH release by FFA elevation in man (8).

Our studies were designed to confirm the reciprocal relationship between the plasma FFA concentration and $\mathrm{HGH}$ release and to gain some insight into its mechanism. More specifically the following questions were posed: (a) Is the HGH response related to the degree/ duration of FFA depression? (b) Can FFA and glucose replace each other in the signal for HGH release? (c) Is FFA lack directly responsible for triggering $\mathrm{HGH}$ release despite the existence of a lag period between FFA depression and $\mathrm{HGH}$ increase? (d) Is the inhibition of HGH release directly due to increased FFA levels, i.e.,

\footnotetext{
${ }^{1}$ Abbreviations used in this paper: BS, blood sugar; FFA, free fatty acid; HGH, human growth hormone; NA, nicotinic acid; NE, norepinephrine.
} 


\begin{tabular}{|c|c|c|}
\hline \multicolumn{2}{|c|}{ PRINCIPLE } & EXPERIMENTAL DESIGN \\
\hline \multirow{4}{*}{$\begin{array}{c}\frac{\text { Group I }}{\text { FFA }} \\
\text { DEPRESSION }\end{array}$} & o. NA I hr alone & NA \\
\hline & b. NA I hr + Glucose & อง \\
\hline & c. NA $5 \mathrm{hr}+$ Glucose & 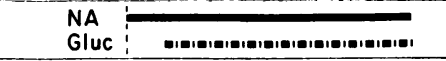 \\
\hline & d. Soline control & Sal \\
\hline \multirow{2}{*}{$\begin{array}{l}\text { GrOUP II } \\
\text { FFA DEPRESSION } \\
\text { FOLLOWED BY } \\
\text { FFA ELEVATION }\end{array}$} & a. NA $90 \mathrm{~min}$ & NA \\
\hline & $\begin{array}{l}\text { NA } 90 \text { min } \\
\text { followed by } \\
\text { Lipid + Heporin }\end{array}$ & - \\
\hline \multirow{4}{*}{$\begin{array}{l}\text { Group III } \\
\text { FFA ELEVATION } \\
\text { PRIOR TO } \\
\text { INSULIN } \\
\text { HYPOGLYCEMIA }\end{array}$} & a. Insulin alone & Ins \\
\hline & b. Lipid + Ins Hypoglyc & Lip - \\
\hline & c. NE + Ins Hypoglyc & NE \\
\hline & d. NE olone & NE \\
\hline & & $\begin{array}{lllllll}-60 & 0 & 60 & 120 & 180 & 240 & 300\end{array}$ \\
\hline
\end{tabular}

FIGURE 1 Schematic outline of the experimental design. Blood sampling began 20 (group I) or $30 \mathrm{~min}$ (groups II and III) before the onset of an infusion. Abbreviations: FFA, free fatty acids; NA, nicotinic acid; NE, norepinephrine; Gluc, glucose; Sal, saline; Lip, lipid-plus-heparin; Ins, insulin.

independent of the method by which FFA concentrations are raised?

We studied: (a) The influence of different amounts of nicotinic acid (NA) infused over different periods of time; $(b)$ The effect of continuous moderate hyperglycemia on HGH release as stimulated by FFA depression; (c) The influence of rapid FFA elevation at the end of the lag period after initial FFA depression; and $(d)$ The effect of different modes of elevation of FFA (lipid infusion/NE infusion) on hypoglycemia-induced $\mathrm{HGH}$ release.

NA lowers the plasma FFA concentration by inhibition of lipolysis in adipose tissue (9). NE increases the plasma FFA concentration by stimulating intracellular lipolysis in adipose tissue (10). Lipid infusion accompanied by heparin administration increases plasma FFA by activation of lipoprotein lipase and its release into the circulation $(11,12)$.

\section{METHODS}

A schematic outline of the principle and of the experimental design of each of the three groups of experiments is given in Fig. 1.

I. (a) NA alone during $1 \mathrm{hr}$. As a pilot study three subjects received an infusion of $1 \mathrm{~g}$ of NA during $1 \mathrm{hr}$ $(16.7 \mathrm{mg} / \mathrm{min})$. Blood was collected during $4 \mathrm{hr}$ after the onset of the infusion.

(b) NA during $1 \mathrm{hr}$ plus glucose. 10 subjects received
NA as in experiment $(a)$ and, in addition, a glucose infusion beginning $40 \mathrm{~min}$ after the onset of the NA infusion and continuing until the end of the experiment. Glucose infusion started at $100 \mathrm{mg} / \mathrm{min}$ and increased up to $400 \mathrm{mg} / \mathrm{min}(800 \mathrm{mg} / \mathrm{min}$ in some cases) in order to assure sustained hyperglycemia during the whole experiment. In four subjects blood was collected during $4 \mathrm{hr}$ and in the other six subjects during $5 \mathrm{hr}$ after the onset of the $\mathrm{Na}$ infusion.

(c) $N A$ during $5 \mathrm{hr}$ plus glucose. 10 subjects received $\mathrm{NA}$ during $1 \mathrm{hr}$ as in experiment $(a)$ followed by NA 0.5 $\mathrm{g} / \mathrm{hr}$ during another $4 \mathrm{hr}$. Glucose was infused as in experiment $(b)$ at a rate of $150 \mathrm{mg} / \mathrm{min}$ for $2 \mathrm{hr}$ and then $200 \mathrm{mg} / \mathrm{min}$ until the end of the experiment.

(d) Saline. As a control 11 subjects received only a slow infusion of normal saline during $5 \mathrm{hr}$.

II. (a) NA alone. 10 subjects received NA during 90 min in increasing amounts: $30 \mathrm{~min}$ each at a rate of 16.7 , 20 , and $27.5 \mathrm{mg} / \mathrm{min}$, respectively, corresponding to a total of $1.9 \mathrm{~g}$ of NA.

(b) NA followed by lipid-plus-heparin. On another day the same subjects received NA as in II $a$, followed immediately by a lipid infusion ${ }^{2}$ at a rate of approximately $2 \mathrm{~g} /$

${ }^{2}$ Lipofundin (B. Braun Melsungen, Germany): cotton seed oil $100 \mathrm{~g}$, soya phosphatides $7.5 \mathrm{~g}, d$-sorbit $50 \mathrm{~g}$ and $d l$-alpha-tocopherol $585 \mathrm{mg}$ in $1000 \mathrm{ml}$ of an oil in water emulsion, corresponding to $1200 \mathrm{Cal} /$ liter. $5000 \mathrm{U}$ of heparin were added to each $500 \mathrm{ml}$ of this emulsion. If added in vitro to the radioimmunoassay system of HGH the heparin concentration caused by this infusion in the plasma will not affect the HGH determination (13). 
$\mathrm{hr}$ and slowly raised within $25 \mathrm{~min}$ to a rate of $12 \mathrm{~g} / \mathrm{hr}$ (200 $\mathrm{mg} / \mathrm{min})$. The lipid infusion was then continued at this rate until the end of the experiment. A total amount of $50 \mathrm{~g}$ of lipid corresponding to $500 \mathrm{ml}$ of the lipid emulsion was infused. Blood was collected during $5 \frac{1}{2} \mathrm{hr}$ after the onset of the NA infusion, corresponding to $4 \mathrm{hr}$ after the onset of the lipid infusion.

III. (a) Insulin alone. In nine subjects hypoglycemia was induced by an i.v. injection of $0.1 \mathrm{IU} / \mathrm{kg}$ of body weight.

(b) Insulin plus lipid-plus-heparin. On another day the same subjects received a lipid infusion as in experiment II $b$. Insulin hypoglycemia was induced $60 \mathrm{~min}$ after the onset of the lipid infusion.

(c) Insulin plus norepinephrine (NE). On a 3rd day these subjects received an infusion of $\mathrm{NE}(18 \mu \mathrm{g} / \mathrm{min})$ during $4 \frac{1}{2} \mathrm{hr}$. Insulin hypoglycemia was induced $30 \mathrm{~min}$ after the onset of the NE infusion.

(d) NE alone. On a 4th day they received only NE as in experiment III $c$. In these experiments blood was collected during $3 \mathrm{hr}$ (experiment III $b$ ) or $4 \mathrm{hr}$ (experiments III $a, c$, and $d$ ) after the insulin injection.

The tests of experiments II and III were done in random order, except that in experiment III the first test was always the NE infusion alone.

None of the volunteers had evidence of endocrinological or metabolic disease or a history of liver disease. For details of sex, age, and weight see Table I. Most of the subjects were medical students and accustomed to comparable experiments. All were informed not to eat after 8 p.m. of the preceding day, not to smoke, drink coffee or tea on the morning of the test day and to avoid physical strain on their way to the hospital.

TABLE I

Clinical Data of Volunteers

\begin{tabular}{|c|c|c|c|c|}
\hline $\begin{array}{l}\text { Experimental } \\
\text { group }\end{array}$ & No. & Sex & Age* & $\begin{array}{c}\text { Percent } \\
\text { ideal } \\
\text { weight*ł }\end{array}$ \\
\hline & & & $y r$ & \\
\hline \multirow[t]{2}{*}{ I a } & 2 & $\mathbf{M}$ & 27.7 & 102 \\
\hline & 1 & $\mathrm{~F}$ & $(27-29)$ & $(98-107)$ \\
\hline \multirow[t]{2}{*}{ I b } & 7 & M & 24.8 & 104.7 \\
\hline & 3 & $\mathrm{~F}$ & $(22-29)$ & $(92-110)$ \\
\hline \multirow[t]{2}{*}{ I c } & 5 & $\mathbf{M}$ & 25.7 & 101.8 \\
\hline & 5 & $\mathrm{~F}$ & $(19-36)$ & $(86-115)$ \\
\hline \multirow[t]{2}{*}{ I d } & 6 & M & 25.1 & 105.2 \\
\hline & 5 & $\mathrm{~F}$ & $(23-28)$ & $(98-119)$ \\
\hline II $a+b$ & 10 & M & $\begin{array}{c}25.1 \\
(21-30)\end{array}$ & $\begin{array}{c}101.9 \\
(88-115)\end{array}$ \\
\hline III $a, b, c, d$ & 9 & $\mathbf{M}$ & $\begin{array}{c}24.6 \\
(21-32)\end{array}$ & $\begin{array}{c}100.4 \\
(92-110)\end{array}$ \\
\hline
\end{tabular}

* Mean and range.

‡ Calculated according to Tables of the Metropolitan Life Insurance Co., Statistical Bulletin 40 (1959) in: Wissenschaftliche Tabellen Geigy, 6th edition. 588.
All experiments were started between 8 and 9 a.m. An indwelling plastic needle for blood collection was placed into an antecubital vein under light local anesthesia and kept patent by a slow drip of normal saline. Another indwelling needle was placed into an antecubital vein of the other arm for the infusions. Blood was collected $20 \mathrm{~min}$ (group I) or $30 \mathrm{~min}$ (groups II and III) and immediately before the onset of an infusion. The exact intervals of further blood collections are indicated in the graphs.

Approximately $10 \mathrm{ml}$ of blood were drawn into centrifuge tubes containing $0.1 \mathrm{ml}$ of heparin $(500 \mathrm{U})$. Blood for determination of glucose was removed immediately and the sample then placed in ice. All samples were centrifuged not later than $2 \mathrm{hr}$ after collection and then plasma for determination of FFA was pipetted into extraction mixture. In some tests plasma samples for FFA determination were kept frozen until assayed. In control experiments no significant difference was seen between samples processed immediately and those kept frozen for several weeks before determination. In other control experiments no difference was seen in the FFA concentration of samples which were centrifuged and extracted immediately after blood collection and portions of the same samples centrifuged up to $2 \mathrm{hr}$ after blood collection and kept in ice thereafter for up to $4 \mathrm{hr}$. Plasma for $\mathrm{HGH}$ determination was frozen immediately after centrifugation and kept at $-25^{\circ} \mathrm{C}$ until assayed.

Blood sugar (BS) was determined enzymatically (Biochimica Test, C. F. Boehringer and Söhne GmbH, Mannheim, Germany) in duplicates. FFA were determined in duplicates according to Dole and Meinertz (14). HGH was determined by radioimmunoassay using a double antibody technique (13). The assay detects $0.5 \mathrm{ng} / \mathrm{ml}$ of plasma. All samples of one test were determined in triplicates of two different dilutions $(1 / 20$ and $1 / 40)$ on the same day. Most samples of subjects who served as their own controls were determined in the same assay. For statistical analysis all HIGH values below $0.5 \mathrm{ng} / \mathrm{ml}$ were counted as $0 \mathrm{ng} / \mathrm{ml}$. Significance of differences between means was calculated according to Student's $t$ test. For groups II and III-in which the subjects served as their own controls-significance of paired differences was also calculated. Results were essentially the same as for the differences of the means. These values are therefore not given.

\section{RESULTS}

I. (a) NA infusion during $1 \mathrm{hr}$, no glucose. In this pilot study the infusion of NA caused a decrease of FFA from $402 \pm 177$ to $212 \pm 43 \mu \mathrm{Eq} /$ liter (mean \pm SEM) in 20 $\min$ and to $125 \pm 13 \mu \mathrm{Eq} /$ liter in $60 \mathrm{~min}$. FFA then remained low despite discontinuation of the NA infusion until a rebound occurred at $240 \mathrm{~min}$ with a maximum of $1815 \pm 362 \mu \mathrm{Eq} /$ liter. BS increased during the NA infusion from $92 \pm 1.0$ to $111 \pm 6.8 \mathrm{mg} / 100 \mathrm{ml}$ at $40 \mathrm{~min}$ and then decreased to basal values at $240 \mathrm{~min}(88 \pm 2.0 \mathrm{mg} /$ $100 \mathrm{ml}$ ).

$\mathrm{HGH}$ was low at the beginning (individual values: $2.8,0.6$, and $0.5 \mathrm{ng} / \mathrm{ml}$ ). There was a minor early rise during the NA infusion in two subjects (to 4.7 and 2.2 $\mathrm{ng} / \mathrm{ml}$, respectively). $\mathrm{HGH}$ increased in all three subjects during the later part of the experiment (to 15.4, 20.0 , and $7.8 \mathrm{ng} / \mathrm{ml}$ at 150,180 , and $180 \mathrm{~min}$, respectively). 
(b) NA infusion during $1 \mathrm{hr}$ plus glucose (Fig. 2). NA infusion caused a comparable decrease of FFA as in experiment $(a)$ : from $519 \pm 43$ to $230 \pm 39 \mu \mathrm{Eq} /$ liter at 60 min. The decrease was significant from $20 \mathrm{~min}$ on $(P<$ 0.01 ) when compared with the zero value, i.e. it was significant before the onset of the glucose infusion at 40 min. A rebound to a maximum of $931 \pm 123 \mu \mathrm{Eq} /$ liter at $240 \mathrm{~min}$ occurred despite the glucose infusion and then FFA dropped to $436 \pm 52 \mu \mathrm{Eq} /$ liter at $300 \mathrm{~min}$. BS values increased during the NA infusion from $86 \pm 2.1$ to $99 \pm 3.7$ $\mathrm{mg} / 100 \mathrm{ml}$ at $50 \mathrm{~min}$. They were then kept at hyperglycemic levels by the glucose infusion with a maximum of $135 \pm 4.4 \mathrm{mg} / 100 \mathrm{ml}$ at $300 \mathrm{~min}$.

HGH increased from $2.1 \pm 1.5$ to $7.8 \pm 2.9 \mathrm{ng} / \mathrm{ml}$ at 30 min. This early rise coincided with the flush produced by the vasodilating action of NA and occurred in 6 of the 10 subjects of this group. HGH then decreased below the initial level to $1.5 \pm 0.4 \mathrm{ng} / \mathrm{ml}$ at $90 \mathrm{~min}$. Despite the elevated BS level a second increase to a maximum of $7.7 \pm 1.9 \mathrm{ng} / \mathrm{ml}$ occurred at $180 \mathrm{~min}$ and $\mathrm{HGH}$ was still elevated to $5.4 \pm 2.1 \mathrm{ng} / \mathrm{ml}$ at $300 \mathrm{~min}$. This late increase was seen in 9 of the 10 subjects. The peak $H G H$ value was attained at different times (150-240 $\mathrm{min})$ though it occurred at $180 \mathrm{~min}$ in 6 of the 9 responding subjects.

(c) NA infusion during $5 \mathrm{hr}$ plus glucose (Fig. 2). In this experiment the NA infusion during the first 60 min was identical to that in the two foregoing experiments. FFA decreased from $640 \pm 76$ to $282 \pm 35 \mu \mathrm{Eq} /$ liter at $60 \mathrm{~min}$ (decrease significant at $20 \mathrm{~min}$ with $P<0.05$ and $P<0.01$ from $30 \mathrm{~min}$ on). Thus, again the FFA decrease was significant before the onset of the glucose infusion. During the following $4 \mathrm{hr}$ (NA infusion 0.5 $\mathrm{g} / \mathrm{hr}$ ) FFA slowly decreased further to $193 \pm 36 \mu \mathrm{Eq} /$ liter at $300 \mathrm{~min}$. There was no FFA rebound under the condition of the continuous NA infusion. BS increased from $90 \pm 3.3$ to $108 \pm 3.9 \mathrm{mg} / 100 \mathrm{ml}$ at $60 \mathrm{~min}$ during the flush period and remained elevated during the glucose infusion (maximum $123 \pm 8.5 \mathrm{mg} / 100 \mathrm{ml}$ at $300 \mathrm{~min}$ ).

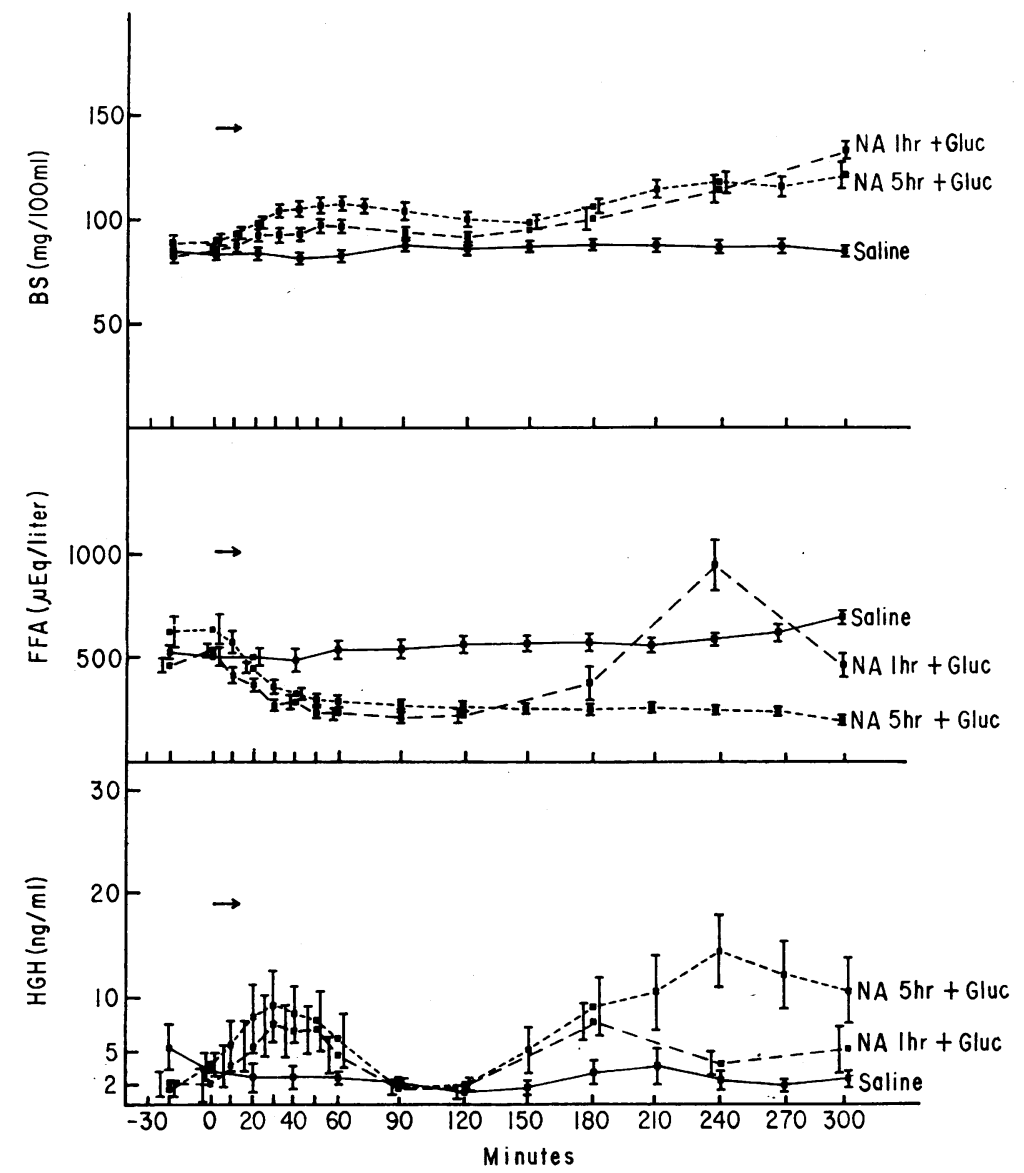

FIgURE 2 BS, FFA, and HGH concentrations during NA infusion (1 hr or $5 \mathrm{hr}$ ) and glucose infusion. Horizontal arrow indicates onset of NA infusion. Glucose infusion was started $40 \mathrm{~min}$ later. Saline controls received neither NA nor glucose. Means and SEM are shown. 
HGH showed an early increase from $3.4 \pm 1.2$ to $9.3 \pm$ $3.3 \mathrm{ng} / \mathrm{ml}$ at $30 \mathrm{~min}$ (not significantly different from the early increase during experiment $\mathrm{I} b$ ) and then decreased below the initial concentration to $1.5 \pm 0.4 \mathrm{ng} / \mathrm{ml}$ at $90 \mathrm{~min}$. A second increase, similar to that in experiment $\mathrm{I} b$ but of greater magnitude and of longer duration, to a maximum of $14.3 \pm 3.6 \mathrm{ng} / \mathrm{ml}$ occurred at 240 min. The individual peak value was attained between 150 and 270 min though in 6 of the 10 subjects it occurred at 180 or $210 \mathrm{~min}$. While the early HGH increase during the flush period was seen only in 6 of the 10 subjects (one male and all five females), the late increase occurred in all 10 subjects.

(d) Saline infusion (Fig. 2). When only saline was infused, FFA decreased minimally from $512 \pm 52$ to $482 \pm$ $56 \mu \mathrm{Eq} /$ liter at $40 \mathrm{~min}$ and then rose slowly to $676 \pm 32$ $\mu \mathrm{Eq} /$ liter at $300 \mathrm{~min}$. Only the $300 \mathrm{~min}$ value was significantly different from the zero level $(P<0.05)$. BS values showed no significant changes. $\mathrm{HGH}$ decreased from $3.3 \pm 1.7$ to $1.2 \pm 0.2 \mathrm{ng} / \mathrm{ml}$ at $120 \mathrm{~min}$. A slight increase at $210 \mathrm{~min}$ to $3.7 \pm 1.8 \mathrm{ng} / \mathrm{ml}$ was entirely due to one female subject who had a peak of $20.8 \mathrm{ng} / \mathrm{ml}$ at this time (the same subject had $\mathrm{HGH}$ values at -30 and zero time of 20.3 and $18.5 \mathrm{ng} / \mathrm{ml}$, respectively, thus causing relatively high mean $\mathrm{HGH}$ concentrations of the saline group at these times). The mean $\mathrm{HGH}$ concentration of the remaining nine subjects at 210 min was 1.7 $\mathrm{ng} / \mathrm{ml}$.

Comparison of $H G H$ values in experiments $I b, c$, and $d$. The HGH concentration during experiment Ib (NA infusion during $1 \mathrm{hr}$ plus glucose) was significantly higher than during the saline infusion at $180 \mathrm{~min}(P<$ 0.025 ). During experiment Ic (NA infusion during $5 \mathrm{hr}$ plus glucose) the HGH values were significantly higher than during the saline infusion at the following times: $180 \mathrm{~min}(P<0.05), 240$ and $270 \mathrm{~min}(P<0.005)$, and $300 \mathrm{~min}(P<0.01)$. The $240 \mathrm{~min}$ value during the longer NA infusion was significantly higher than during the shorter NA infusion $(P<0.05)$. Due to the large scatter of values during the flush period the mean values of experiments $\mathrm{I} b$ and $\mathrm{I} c$ were not significantly different from those of the saline group during the early $\mathrm{HGH}$ rise.

In the experiments of group I $(a-d)$ male and female subjects were used in order to detect a possible sex difference. The late $\mathrm{HGH}$ response to the FFA depression was however similar in both sexes $(P>0.05$ for mean difference of $\mathrm{HGH}$ concentrations in males and females), while there was a great variability of $\mathrm{HGH}$ concentrations before the onset of the infusions and during the flush period in the females. In the following experiments only male subjects were therefore studied.

II. (a) NA infusion during 90 min, no lipid (Fig. 3). During this NA infusion FFA decreased from $510 \pm 68$ to $270 \pm 59 \mu \mathrm{Eq} /$ liter at $90 \mathrm{~min}$ (decrease significant with $P<0.05$ at $30 \mathrm{~min}$ and $P<0.01$ from $45 \mathrm{~min}$ on). FFA remained low until $210 \mathrm{~min}$ (i.e. $120 \mathrm{~min}$ after the end of the NA infusion) and then increased to a rebound value of $1792 \pm 302 \mu \mathrm{Eq} /$ liter at $330 \mathrm{~min}$. BS increased from $84 \pm 5.5$ to $94 \pm 5.7 \mathrm{mg} / 100 \mathrm{ml}(45 \mathrm{~min})$, then decreased slowly towards the preinfusion concentration.

$\mathrm{HGH}$ increased from $1.5 \pm 1.1$ to $4.5 \pm 2.0 \mathrm{ng} / \mathrm{ml}$ at 45 min during the flush period, then decreased to $0.4 \pm 0.3$ $\mathrm{ng} / \mathrm{ml}$ at $120 \mathrm{~min}$ and increased again to $8.4 \pm 2.5 \mathrm{ng} / \mathrm{ml}$ at $240 \mathrm{~min}$. It was still elevated to $3.4 \pm 3.0 \mathrm{ng} / \mathrm{ml}$ at 330 $\min$.

(b) NA infusion during 90 min followed by lipid-plusheparin (Fig. 3). FFA decreased during the NA infusion from $727 \pm 113$ to $399 \pm 59 \mu \mathrm{Eq} /$ liter at $90 \mathrm{~min}$ (decrease significant from $45 \mathrm{~min}$ on with $P<0.05$ ). The mean FFA concentration in this experiment was somewhat higher than during experiment II $a$ before and during the NA infusion. However, this difference was never statistically significant. Immediately after the onset of the lipid infusion FFA began to rise from the depressed level, attained the initial value within $30 \mathrm{~min}$ at $720 \pm 89$ $\mu \mathrm{Eq} /$ liter and reached a maximum of $2876 \pm 349 \mu \mathrm{Eq} /$ liter at $300 \mathrm{~min}$. When compared with the $90 \mathrm{~min}$ value (end of the NA infusion) the increase was significant from $120 \mathrm{~min}$ on (i.e. from $30 \mathrm{~min}$ later $)(P<0.01)$. BS increased during the NA infusion from $82 \pm 4.0$ to $95 \pm 4.6$ $\mathrm{mg} / 100 \mathrm{ml}$ at $30 \mathrm{~min}$, then decreased to $79 \pm 4.3 \mathrm{mg} / 100$ $\mathrm{ml}$ at $120 \mathrm{~min}$ and slowly increased again during the lipid infusion to $90 \pm 3.9 \mathrm{mg} / 100 \mathrm{ml}$ at $270 \mathrm{~min}$. The mean BS concentrations of experiments II $a$ and II $b$, respectively, were not significantly different during the whole experiment.

HGH increased during the flush period from $0.4 \pm 0.2$ to $5.4 \pm 2.1 \mathrm{ng} / \mathrm{ml}$ at $30 \mathrm{~min}$ and then decreased to $1.0 \pm$ $0.4 \mathrm{ng} / \mathrm{ml}$ at $90 \mathrm{~min}$. It then remained low, the highest concentration reached thereafter being $1.7 \pm 0.6 \mathrm{ng} / \mathrm{ml}$ at 210 and $240 \mathrm{~min}$. HGH values were significantly lower than during experiment II $a$ at 210 and $300 \mathrm{~min}(P<$ $0.025)$ and 240 and $270 \min (P<0.005)$.

III. (a) Insulin hypoglycemia alone (Fig. 4). I.v. injection of insulin caused a BS decrease from $84 \pm 3.4$ to $29 \pm 2.3 \mathrm{mg} / 100 \mathrm{ml}$, the nadir occurring $30 \mathrm{~min}$ after the injection. All subjects had BS nadirs of $35 \mathrm{mg} / 100 \mathrm{ml}$ or lower. FFA decreased from $567 \pm 95$ to $285 \pm 28 \mu \mathrm{Eq} /$ liter at $30 \mathrm{~min}$. HGH increased from $0.9 \pm 0.3$ to $32.2 \pm 6.5 \mathrm{ng} /$ $\mathrm{ml}$, the maximum occurring at $60 \mathrm{~min}$.

(b) Insulin hypoglycemia during lipid-plus-heparin infusion (Fig. 4). FFA were raised by the lipid infusion from $713 \pm 89$ to $1537 \pm 162 \mu \mathrm{Eq} /$ liter within $60 \mathrm{~min}$ (change significant with $P<0.05$ at $30 \mathrm{~min}$ and $P<$ 0.01 at $60 \mathrm{~min}$ ). They decreased to $1176 \pm 88 \mu \mathrm{Eq} /$ liter 20 min after the insulin injection and increased again to a maximum of $1974 \pm 217 \mu \mathrm{Eq} /$ liter at $180 \mathrm{~min}$ after in- 


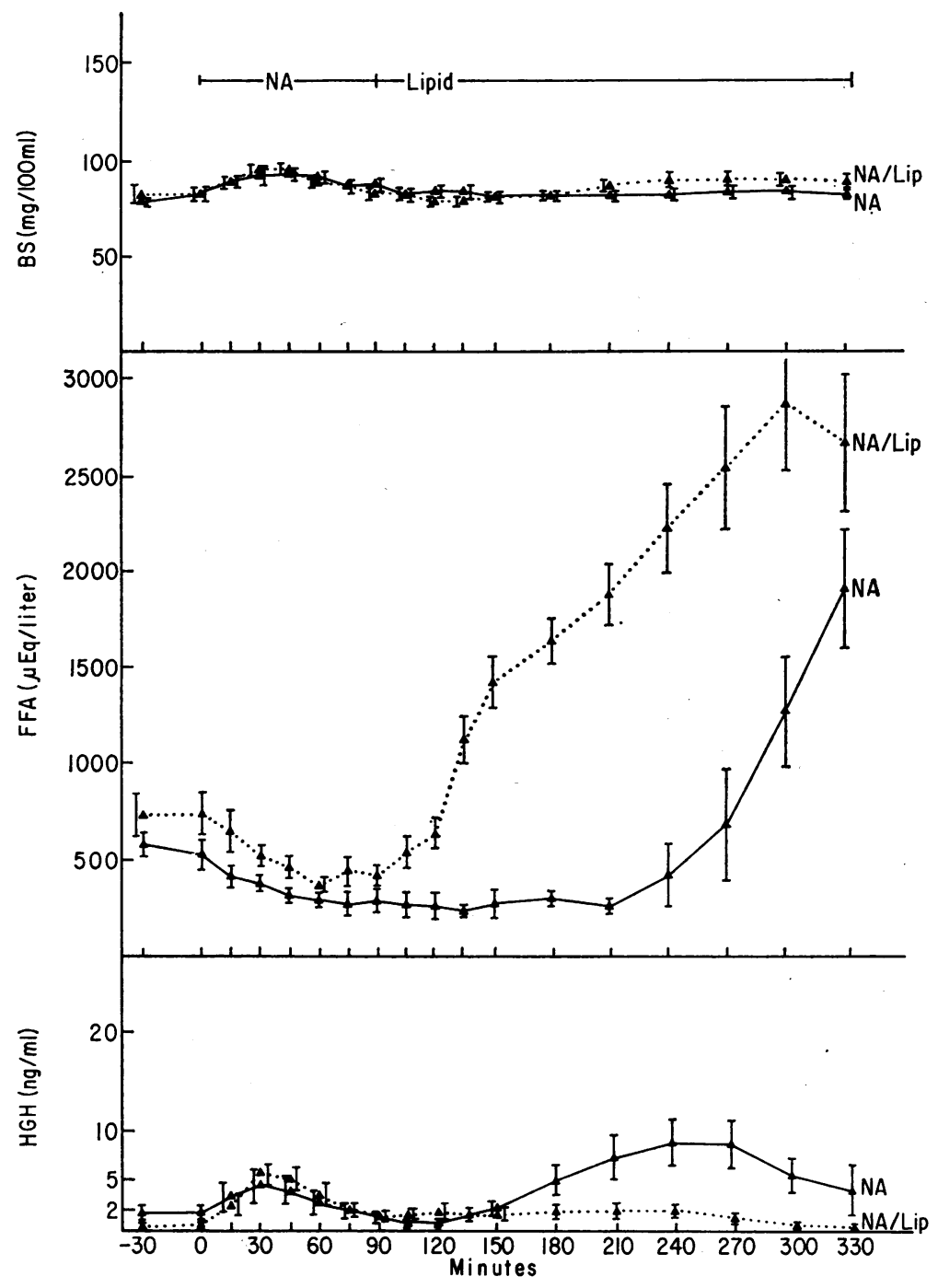

FIGURE 3 BS, FFA, and HGH concentrations during NA infusion alone (90 $\mathrm{min}$ ) and during NA infusion followed by lipid-plus-heparin infusion. Means and SEM are shown.

sulin. The FFA concentration greatly exceeded that of the control test (insulin alone) during the entire test period. The hypoglycemic effect of insulin was fully preserved in the presence of elevated FFA: BS decreased from $83 \pm 2.0$ to $28 \pm 1.0 \mathrm{mg} / 100 \mathrm{ml}$ at $30 \mathrm{~min}$.

$\mathrm{HGH}$ increased from $1.4 \pm 0.8$ to $11.4 \pm 1.6 \mathrm{ng} / \mathrm{ml}$ at $60 \mathrm{~min}$ after insulin, significantly less than during insulin injection alone (difference from control test significant at $45 \mathrm{~min}$ with $P<0.025$, at 60 and $180 \mathrm{~min}$ with $P<0.005$, and at 90 and $120 \mathrm{~min}$ with $P<0.0005$ ).

(c) Insulin hypoglycemia during NE infusion (Fig. 4). FFA were raised by the NE infusion from $563 \pm 101$ to $1405 \pm 169 \mu \mathrm{Eq} /$ liter within 30 min (change significant at $15 \mathrm{~min}$ with $P<0.05$ and at $30 \mathrm{~min}$ with $P<0.01$ ).
They decreased to $516 \pm 52 \mu \mathrm{Eq} /$ liter 30 min after the insulin injection and increased again to a maximum of $1666 \pm 146 \mu \mathrm{Eq} /$ liter at $240 \mathrm{~min}$. Thus the absolute FFA decrease was much greater in this group than either during insulin injection alone or when FFA were initially raised by lipid infusion. During the entire experiment FFA levels were intermediate between those of experiment III $a$ (insulin alone) and experiment III $b$ (lipid infusion). BS values first increased under the influence of the $\mathrm{NE}$ infusion from $84 \pm 2.9$ to $105 \pm 4.1 \mathrm{mg} / 100 \mathrm{ml}$, then decreased to $32 \pm 1.4 \mathrm{mg} / 100 \mathrm{ml} 30 \mathrm{~min}$ after the insulin injection and rose again to levels slightly higher than during the lipid infusion experiment $(105 \pm 4.4 \mathrm{mg} /$ $100 \mathrm{ml}$ at $180 \mathrm{~min}$ ). The absolute BS decrease was thus 


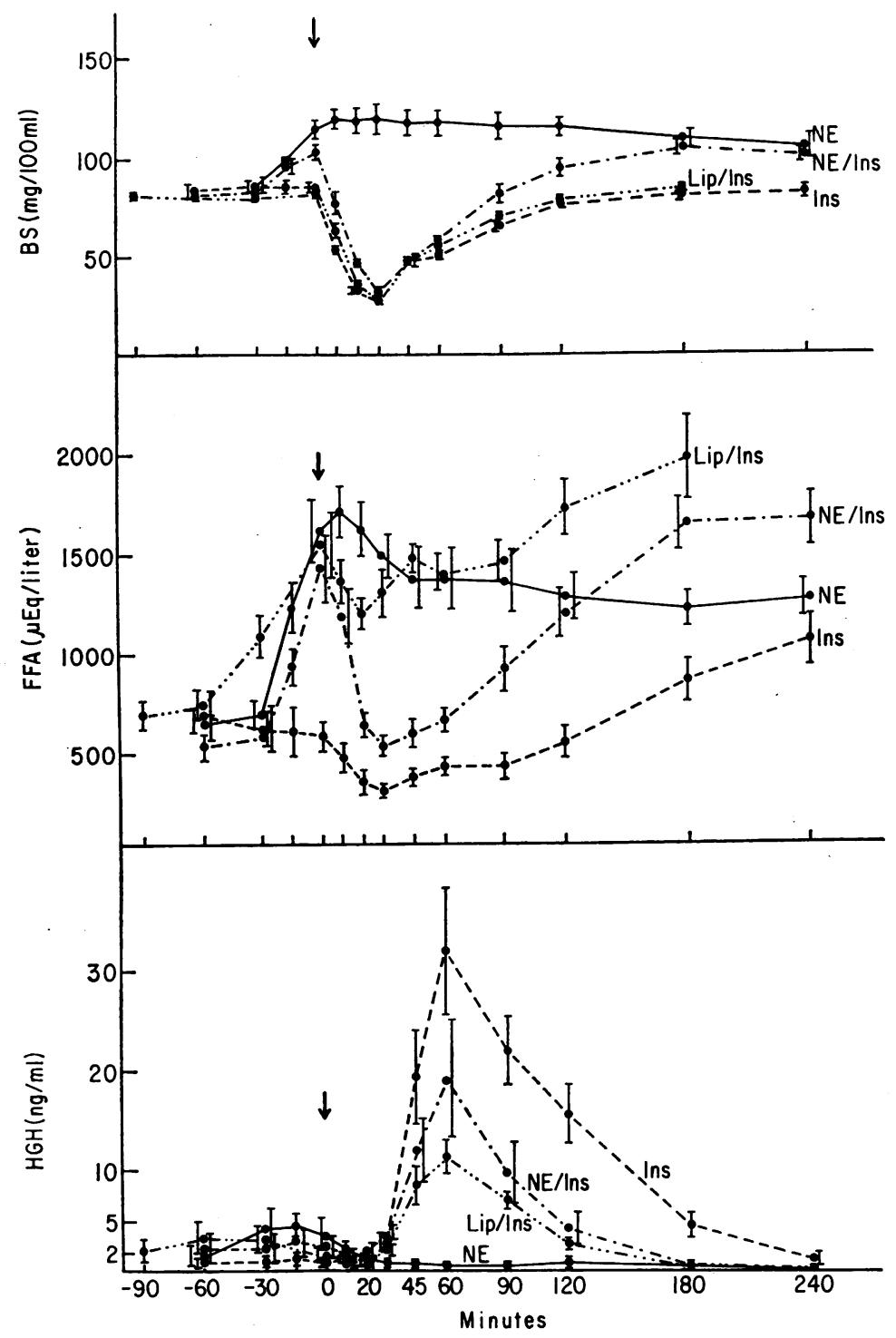

FIgURE 4 BS, FFA, and HGH concentrations during insulin hypoglycemia preceded by lipid-plus-heparin or NE infusion. Arrow indicates time of i.v. injection of 0.1 IU of crystalline insulin. Ins, control experiment without prior FFA elevation; NE, control experiment without insulin injection. Means and SEM are shown.

greater than during experiment III $a$ or $b$, due to the prior catecholamine-induced BS elevation ( 72 vs. 55 and $55 \mathrm{mg} / 100 \mathrm{ml}$, respectively).

HGH rose from $2.4 \pm 1.1$ to $19.0 \pm 6.2 \mathrm{ng} / \mathrm{ml}$ at $60 \mathrm{~min}$ after insulin. This increase is significantly smaller than during the control test (insulin alone) at $90 \mathrm{~min}(P<$ $0.01)$ and 120 and $180 \mathrm{~min}(P<0.0025)$. The inhibition of the HGH increase was however slightly less pronounced than that achieved by the lipid infusion, though the difference between the HGH concentration of ex- periment III $b$ and III $c$, respectively, was significant only at $180 \mathrm{~min}(P<0.05)$.

(d) NE infusion alone (Fig. 4). NE infusion raised FFA levels from $667 \pm 96$ to $1689 \pm 137 \mu \mathrm{Eq} /$ liter at 40 min after the onset of the infusion, followed by a slow decrease to $1202 \pm 96 \mu \mathrm{Eq} /$ liter at $180 \mathrm{~min}$. BS values increased from $83 \pm 3.8$ to $121 \pm 4.0 \mathrm{mg} / 100 \mathrm{ml}$ at $40 \mathrm{~min}$, then decreased gradually to $104 \pm 5.8 \mathrm{mg} / 100 \mathrm{ml}$ at 240 min despite the continuation of the infusion.

$\mathrm{HGH}$ was highest $15 \mathrm{~min}$ after the onset of the $\mathrm{NE}$ 


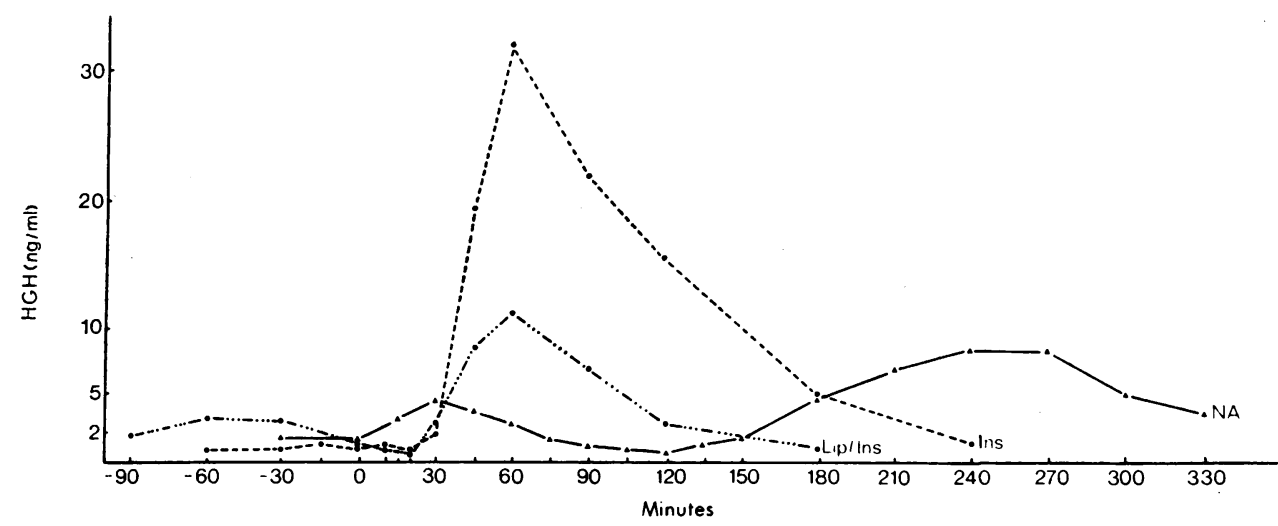

FIGURE 5 Comparison of mean HGH values during insulin hypoglycemia alone, insulin hypoglycemia preceded by lipid infusion, and during NA-induced FFA depression (groups III $a$, III $b$, and II $a$, respectively). Note late onset and submaximal degree of HGH increase when stimulated by FFA depression as compared with insulin hypoglycemia.

infusion $(4.4 \pm 1.7 \mathrm{ng} / \mathrm{ml})$, then decreased slowly without a new elevation. Indeed, the HGH concentrations in this group were lower during the entire time after the small early elevation than during the saline experiment $(I d)$, though the difference between the mean HGH values of these two tests never reached significance.

\section{DISCUSSION}

These results confirm the reports of Irie et al. (3) that NA-induced FFA depression is followed by an increase of $\mathrm{HGH}$ with a lag period of about $2 \mathrm{hr}$ and of Blackard et al. (6) that elevation of FFA inhibits hypoglycemia-induced $\mathrm{HGH}$ release. The mechanism of this relationship has not been elucidated. Tsushima et al. (4) suggested that the acute reduction of energy fuel for the hypothalamus in the form of FFA is the signal for $\mathrm{HGH}$ release. They concluded that. FFA and glucose can substitute for each other as an energy substrate since glucose administration prevented the HGH increase that otherwise followed FFA decrease from elevated levels. Though our experimental design was somewhat different, our results fail to support this thesis. In experiments $\mathrm{I} b$ and $c$, after an early BS increase (which may be due to a direct hyperglycemic effect of NA (15)) constant moderate hyperglycemia was maintained. Since glucose-induced insulin secretion is not diminished by NA (15) and glucose turnover is even increased during NA-induced FFA depression in the dog (16), it can be assumed, that the administered glucose was fully available to the cells. Yet, HGH levels increased significantly following the FFA depression. On the other hand-in accordance with the results of Blackard et al. (6)-the HGH response to insulin hypoglycemia was diminished but not abolished in the presence of elevated FFA levels, demonstrating that even during abundance of FFA the hypothalamic GH-releasing mechanism responds to glucose lack. Furthermore, exercise-induced $\mathrm{HGH}$ release-usually interpreted as reflecting a state of acute energy need-is prevented by glucose but not by lipid administration $(17,8)$. Here again apparently FFA and glucose are not interchangeable in their influence on $\mathrm{HGH}$ release. The relationship between FFA and other stimuli of $\mathrm{HGH}$ secretion may be different since arginine-induced $\mathrm{HGH}$ release is abolished by FFA elevation (6). Whether higher BS levels than those attained in our experiments-which were roughly equivalent to those reported by Tsushima et al. (4) are more effective to suppress the $\mathrm{HGH}$ response to FFA depression, remains to be investigated.

The lag period between FFA depression and HGH increase (which somewhat recalls the latency in onset of the hormone's lipolytic effect $(1,2)$ ) was essentially the same in the absence and the presence of hyperglycemia and identical to that reported after i.m. administration of NA by Irie et al. (3). Its cause is unknown. One possible explanation would be that the breakdown of an intracellular reservoir of triglycerides - not affected by NA-could substitute during a certain time for the diminishing supply of plasma FFA. The wide scatter in the time of onset of the $\mathrm{HGH}$ response after FFA depression could then tentatively be explained by variations in the intracellular triglyceride stores at the hypothalamic level. There is indirect evidence that not all tissues participate in the NA-induced inhibition of lipolysis (18). However, practically nothing is known about the lipid metabolism of the hypothalamus, though the FFA concentration of this area has recently been found (in the rat) to be much higher than in other parts of the brain (19). FFA have also been suggested to play a role in postsynaptic membrane permeability in the brain, but these 
are thought to be derived from brain phospholipids rather than from peripheral sources $(20)$. On the other side, a small but apparently significant amount of FFA is taken up from the blood into the brain and there incorporated into lipids (21). Whether these findings have any significance for the relationship between plasma FFA and $\mathrm{HGH}$ secretion remains at present obscure.

Acute supply of FFA at the end of the lag period prevented the expected $\mathrm{HGH}$ increase. FFA enter the cells very rapidly having a plasma half-time of only 2-4 min (22) and can thus quickly restore the intracellular FFA reservoir. The rapid effect of FFA elevation at the end of the lag period favors but does not prove the concept that FFA lack is directly responsible for the $\mathrm{HGH}$ release.

During the $5 \mathrm{hr}$ NA infusion the degree of FFA depression and the absolute FFA levels were essentially the same as during the $1 \mathrm{hr}$ NA infusion, but the duration of FFA depression was longer and the FFA rebound was prevented. The $\mathrm{HGH}$ increase was significantly greater than during the shorter FFA suppression, suggesting that the duration of the FFA decrease is important for the magnitude of the HGH response. However, it is not possible to differentiate between the effect of a prolonged FFA depression and the absence of a suppressive effect of the FFA rebound on $\mathrm{HGH}$ release. The $\mathrm{HGH}$ increase in the absence of a FFA rebound rules out the possibility (26) that the secondary increase rather than the decrease of FFA might be the cause of $\mathrm{HGH}$ release after NA administration. No apparent relation could be found between the magnitude of individual HGH increases and the corresponding FFA rebound and the HGH increase preceded the FFA rebound in most but not in all subjects. Absence of such a relation has also been reported in the monkey (7). This supports the view that factors other than $\mathrm{HGH}$ are more important for the FFA rebound, but does not exclude its participation in those cases in which the HGH increase occurs early enough before the rebound $(24,25)$. When the FFA infusion was extended to $5 \mathrm{hr}$, half of the subjects complained about abdominal discomfort and nausea. ${ }^{3}$ While we think that the early HGH increase in some of the subjects during NA infusion is due to the stress of the flush period together with apprehension at the beginning of test, the larger $\mathrm{HGH}$ increase during the later part of the $5 \mathrm{hr}$ NA infusion is probably unrelated to stress. HGH levels were already decreasing when these symptoms occurred and no new

\footnotetext{
'These symptoms are reminiscent of those of the Jamaican vomiting sickness in which inhibition of FFA oxidation is one important factor (23). However, a direct effect of the prolonged NA infusion cannot be ruled out.
}

increase was seen. Moreover, there was no relation between the gravity of these symptoms and the magnitude of individual $\mathrm{HGH}$ increases.

Stimulation of $\mathrm{HGH}$ release by FFA depression (whether or not accompanied by glucose infusion) was submaximal when compared with that seen during insulin hypoglycemia. Indeed it equaled only that which persisted when hypoglycemia-induced HGH release took place in the presence of elevated FFA levels (Fig. 5 ). It seems that FFA depression is a less potent stimulus of $\mathrm{HGH}$ release than insulin hypoglycemia. The apparent slow onset of HGH increase after FFA depression in the curves representing mean values is, however, a result of the scatter in the time of onset of the increase between individuals. Rises of more than $10 \mathrm{ng} / \mathrm{ml}$ within $30 \mathrm{~min}$ were seen in more than onethird of the subjects, making it very probable that HGH release and not a decrease in the rate of degradation was responsible for the changes in the $\mathrm{HGH}$ plasma concentration.

In contrast to the lag period involved in $\mathrm{HGH}$ release after FFA depression the inhibitory effect of FFA elevation on $\mathrm{HGH}$ secretion was observed when FFA were increased only $30 \mathrm{~min}$ before induction of hypoglycemia. Two different ways were used for raising FFA is order to try to rule out direct influences of the substances used on $\mathrm{HGH}$ release. That both methods proved effective to inhibit HGH release provides evidence that in fact elevation of FFA and not constituents of the lipid mixture, heparin, or NE were responsible for the inhibition. Blackard et al. have shown, that neither triglycerides nor ketone bodies can account for the suppressive effect of lipids on GH release $(5,6)$. NE has predominantly alpha adrenergic stimulatory activity (27) and $\mathrm{HGH}$ secretion is enhanced by stimulation of alpha adrenergic receptors $(28,29)$. While the effect of systemically administered $\mathrm{NE}$ on HGH release has not been studied before, epinephrine stimulates $\mathrm{HGH}$ secretion in the presence of beta adrenergic blocking agents but not when given alone $(30,31)$. In our experiments, when $\mathrm{NE}$ alone was infused, no $\mathrm{HGH}$ increase was seen. In fact, HGH concentration was even lower than during saline infusion, suggesting that the effect of elevated FFA overpowered any possible influence of alpha adrenergic stimulation on $\mathrm{HGH}$ release. That $\mathrm{NE}$ was somewhat less effective in suppressing $\mathrm{HGH}$ secretion than lipid infusion can therefore not be ascribed to activation of alpha adrenergic receptors. It may be due to the greater insulin-induced FFA decrease in the NE experiment. Since a fall of FFA from elevated levels can stimulate $\mathrm{HGH}$ secretion (4) this could have counteracted the inhibitory influence of the prior FFA elevation thus resulting in less net inhibition of $\mathrm{HGH}$ release. 
Depression of HGH secretion by elevated FFA and stimulation of $\mathrm{HGH}$ secretion by depression of FFA together with the lipolytic effect of the hormone provide the basic requirements for a negative feedback loop between the plasma FFA concentration and $\mathrm{HGH}$ secretion. The timing of responses in this feedback makes it important for subacute rather than for acute changes of FFA levels. The role of $\mathrm{HGH}$ for the mobilization of FFA during fasting $(32,33)$ and after exercise $(17,34)$ has recently been questioned $(35,36)$, and human dwarfs with an isolated HGH deficiency have been reported to have elevated rather than low FFA and to mobilize FFA adequately during fasting (37). However, their lower than normal insulin levels may facilitate FFA mobilization in the absence of $\mathrm{HGH}$. Existing relations between $\mathrm{HGH}$ secretion and the plasma FF concentration may often be obscured by such factors as the delay of the HGH rise after FFA depression, the delay in the onset of the lipolytic action of the hormone, by the wide scatter of the time of onset of an $\mathrm{HGH}$ rise after FFA suppression between individuals and by the tendency of $\mathrm{HGH}$ to be secreted in bursts rather than continuously even during persistence of the stimulus (17).

\section{ACKNOWLEDGMENTS}

Expert technical assistance was given by Mrs. Astrid Potthoff and Miss Barbara Mönnikes.

We are grateful to Dr. J. S. Soeldner, Boston, for helpful criticism during the preparation of the manuscript.

\section{REFERENCES}

1. Raben, M. S., and C. H. Hollenberg. 1959. Effect of growth hormone on plasma fatty acids. J. Clin. Invest. 38: 484.

2. Rabinowitz, D., G. A. Klassen, and K. L. Zierler. 1965. Effect of human growth hormone on muscle and adipose tissue metabolism in the forearm of man. J. Clin. Invest. $44: 51$.

3. Irie, M., M. Sakuma, T. Tsushima, K. Shizume, and K. Nakao. 1967. Effect of nicotinic acid administration on plasma growth hormone concentrations. Proc. Soc. Exp. Biol. Med. 126 : 708.

4. Tsushima, T., F. Matsuzaki, and M. Irie. 1970. Effect of heparin administration on plasma growth-hormone concentrations. Proc. Soc. Exp. Biol. Med. 133: 1084.

5. Blackard, W. G., C. T. Boylen, T. C. Hinson, and N. C. Nelson. 1969. Effect of lipid and ketone infusions on insulin-induced growth hormone elevations in rhesus monkeys. Endocrinology. 85: 1180.

6. Blackard, W. G., E. W. Hull, and A. Lopez-S. 1971. Effect of lipids on growth hormone secretion in humans. J. Clin. Invest. 50: 1439.

7. Blackard, W. G., and S. A. Heidingsfelder. 1969. Effect of adrenergic receptor blockade on nicotinic acid-induced plasma FFA rebound. Metab. (Clin. Exp.). 18: 226.

8. Hansen, AA. P. 1971. The effect of intravenous infusion of lipids on the exercise-induced serum growth hor- mone rise in normals and juvenile diabetics. Scand. J. Clin. Lab. Invest. 28: 207.

9. Carlson, L. A., and L. Orö. 1962. The effect of nicotinic acid on the plasma free fatty acids: demonstration of a metabolic type of sympathicolysis. Acta Med. Scand. 172: 641.

10. Maickel, R., H. Sussman, K. Yamada, and B. Brodie. 1963. Control of adipose tissue lipase activity by the sympathetic nervous system. Life Sci. 2: 210.

11. Schalch, D. S., and D. M. Kipnis. 1965. Abnormalities in carbohydrate tolerance associated with elevated plasma nonesterified fatty acids. J. Clin. Invest. 44: 2010.

12. Robinson, D. S., and P. M. Harris. 1959. The production of lipolytic activity in the circulation of the hind limb in response to heparin. Quart. J. Exp. Physiol. 44: 80 .

13. Quabbe, H.-J. 1969. Radioimmunologische Bestimmung von Wachstumshormon im Plasma des Menschen. $Z$. Klin. Chem. Klin. Biochem. 7: 259.

14. Dole, V. P., and H. Meinertz. 1960. Microdetermination of long-chain fatty acids in plasma and tissues. J. Biol. Chem. 235 : 2595.

15. Miettinen, T. A., M.-R. Taskinen, R. Pelkonen, and E. A. Nikkilä. 1969. Glucose tolerance and plasma insulin in man during acute and chronic administration of nicotinic acid. Acta Med. Scand. 186: 247.

16. Paul, P., B. Issekutz, Jr., and H. I. Miller. 1966. Interrelationship of free fatty acids and glucose metabolism in the dog. Am. J. Physiol. 211: 1313.

17. Hunter, W. M., C. C. Fonseka, and R. Passmore. 1965. The role of growth hormone in the mobilization of fuel for muscular exercise. Quart. J. Exp. Physiol. 50: 406.

18. Carlson, L. A., S. O. Fröberg, and E. R. Nye. 1966. Acute effects of nicotinic acid on plasma, liver, heart and muscle lipids. Acta Med. Scand. 180: 571.

19. Bazán, N. G., Jr., H. E. P. de Bazán, W. G. Kennedy, and C. D. Joel. 1971. Regional distribution and rate of production of free fatty acids in rat brain J. Neurochem. 18: 1387.

20. Lunt, G. G., and C. E. Rowe. 1971. The effect of cholinergic substances on the production of unesterified fatty acids in brain. Brain Res. 35: 215.

21. Dhopeshwarkar, G. A., and J. F. Mead. 1969. Fatty acid uptake by the brain. II. Incorporation of $\left(\mathrm{I}^{-14} \mathrm{C}\right)$ palmitic acid into the adult rat brain. Biochim. Biophys. Acta. 187: 461 .

22. Laurell, S. 1957. Turnover rate of unesterified fatty acids in human plasma. Acta Physiol. Scand. 41: 158.

23. Von Holt, C., M. von Holt, and H. Böhm. 1966. Metabolic effects of hypoglycin and methylenecyclopropaneacetic acid. Biochim. Biophys. Acta. 125: 11.

24. Irie, M., T. Tsushima, and M. Sakuma. 1970. Effect of nicotinic acid administration on plasma $\mathrm{HGH}, \mathrm{FFA}$ and glucose in obese subjects and in hypopituitary patients. Metab. (Clin. Exp.). 19: 972.

25. Tsushima, T., M. Sakuma, and M. Irie. 1970. Effect of changes in plasma free fatty acids level on secretion of human growth hormone. Endocrinol. Jap. 17: 369.

26. Yates, F. E., S. M. Russell, and J. W. Maran. 1971. Brain-adenohypophyseal communication in mammals. Ann. Rev. Physiol. 33 : 393.

27. Goodman, L. S., and A. Gilman. 1965. The pharmacological basis of therapeutics. The Macmillan Co., New York. 3rd edition. 496.

28. Blackard, W. G., and S. A. Heidingsfelder. 1968. Adren- 
ergic receptor control mechanism for growth hormone secretion. J. Clin. Invest. $47: 1407$.

29. Imura, H., Y. Kato, M. Ikeda, M. Morimoto, and M. Yawata. 1971. Effect of adrenergic-blocking or -stimulating agents on plasma growth hormone, immunoreactive insulin, and blood free fatty acid levels in man. J. Clin. Invest. 50: 1069.

30. Blackard, W. G., and G. J. Hubbell. 1970. Stimulatory effect of exogenous catecholamines on plasma $\mathrm{HGH}$ concentrations in presence of beta adrenergic blockade. Metab. (Clin. Exp.). 19: 547.

31. Massara, F., and E. Strumia. 1970. Increase in plasma growth hormone concentration in man after infusion of adrenaline-propranolol. J. Endocrinol. 47: 95.

32. Hunter, W. M., and F. C. Greenwood. 1964. Studies on the secretion of human-pituitary-growth hormone. Brit. Med.J. I: 804.

33. Glick, S. M., J. Roth, R. S. Yalow, and S. A. Berson.
1965. The regulation of growth hormone secretion. Rec. Progr. Hormone Res. 21: 241.

34. Schalch, D. S. 1967. The influence of physical stress and exercise on growth hormone and insulin secretion in man. J. Lab. Clin. Med. $69: 256$.

35. Cahill, G. F., Jr., M. G. Herrera, A. P. Morgan, J. S. Soeldner, J. Steinke, P. L. Levy, G. A. Reichard, Jr., and D. M. Kipnis. 1966. Hormone-fuel interrelationships during fasting. J. Clin. Invest. 45: 1751.

36. Hartog, M., R. J. Havel, G. Copinschi, J. M. Earll, and B. C. Ritchie. 1967. The relationship between changes in serum levels of growth hormone and mobilization of fat during exercise in man. Quart. J. Exp. Physiol. 52 : 86.

37. Merimee, T. J., P. Felig, E. Marliss, S. E. Fineberg, and G. F. Cahill, Jr. 1971. Glucose and lipid homeostasis in the absence of human growth hormone. $J$. Clin. Invest. $50: 574$. 